\title{
Dietary protein levels in Piaractus brachypomus submitted to extremely acidic or alkaline $\mathrm{pH}$
}

\author{
Níveis de proteína na dieta de Piaractus brachypomus submetidos \\ a pH extremamente ácidos ou alcalinos
}

\author{
Luciano de Oliveira Garcia ${ }^{\mathrm{I}}$ Mariana Gutiérrez-Espinosa ${ }^{\mathrm{II}}$ \\ Walter Wásquez-Torres ${ }^{\mathrm{II}}$ Bernardo Baldisserotto ${ }^{\mathrm{III}}$
}

\section{ABSTRACT}

The objective this study was to evaluate the effects of dietary protein levels in pirapitinga, Piaractus brachypomus, submited to extremely acidic or alkaline $\mathrm{pH}$. Juveniles were fed for 20 days with three diets with different crude protein $(C P)$ levels $(25.3,32.4$ and $40.0 \%)$ and then separated in five groups $(n=10$, three replicates each) which were kept in $60 \mathrm{~L}$ aquaria and exposed to $\mathrm{pH} 3.0,3.5$, 7.0, 10, or 10.5. Fish were removed from aquaria when they showed loss of swimming balance, and then blood was collected and plasma separated for measurement of $\mathrm{Na}^{+}, \mathrm{Cl}^{\text {and }} \mathrm{K}^{+}$levels. The increase of dietary protein levels (up to $40.0 \% \mathrm{CP}$ ) provided some protection for pirapitinga at $p H 3.5$ or 10.0 because the time to lose equilibrium increased after acute exposure, but was not effective for compensating ion loss at very acidic ( $\mathrm{Na}^{+}$and $\mathrm{Cl}$ ) and alkaline $(\mathrm{Cl}) \mathrm{pH}$.

Key words: pirapitinga, fish, ionoregulation, extreme $\mathrm{pH}$.

RESUMO

O objetivo deste estudo foi avaliar o efeito dos níveis de proteína na dieta de pirapitinga, Piaractus brachypomus, submetidas a $\mathrm{pH}$ extremamente ácido ou alcalino. Os juvenis foram alimentados durante 20 dias com três dietas com diferentes níveis de proteína bruta (PB) $(25,3 ; 32,4$ e 40,0\%) e, em seguida, foram separados em cinco grupos ( $n=10$, três repetições cada), os quais foram colocados em aquários de 60L e expostos aos $p H$ 3,0; 3,5; 7,0; 10 ou 10,5. Os peixes foram removidos dos aquários quando apresentaram perda de equilíbrio natatório, o sangue foi então coletado e o plasma separado para determinação dos níveis de $\mathrm{Na}^{+}, \mathrm{Cl}^{-}$e $\mathrm{K}^{+}$. O aumento dos níveis de proteína na dieta (até $40 \%$ $P B)$ forneceu alguma proteção para pirapitingas em $\mathrm{pH} 3,5$ ou 10,0, porque o tempo para perder o equilíbrio natatório aumentou após a exposição aguda, mas não foi efetivo para compensar a perda de íons em $\mathrm{pH}$ muito ácido $\left(\mathrm{Na}^{+}\right.$e $\mathrm{Cl}$ ) ou alcalino $(\mathrm{Cl})$.

Palavras-chave: pirapitinga, peixe, ionorregulação, pH extremos.

\section{INTRODUCTION}

Fish exposed to acidic $\mathrm{pH}$ presented net $\mathrm{Na}^{+}, \mathrm{K}^{+}$and $\mathrm{Cl}^{-}$effluxes, with consequent decrease of ion plasma levels (D'CRUZ \& WOOD, 1998; PARRA \& BALDISSEROTTO, 2007). Exposure of rainbow trout Oncorhynchus mykiss to alkaline waters also reduced branchial uptake and plasma $\mathrm{Na}^{+}$ and $\mathrm{Cl}^{-}$levels, with no effect on branchial diffusive efflux (YESAKI \& IWAMA, 1992; WILKIE et al., 1996), and silver catfish Rhamdia quelen presented higher net $\mathrm{Na}^{+}$loss (COPATTI et al., 2011). The ion loss in fish exposed to acidic and alkaline $\mathrm{pH}$ can be compensated by ion dietary uptake because when fish are fed adequately this ionoregulatory disturbance is minimized (DOCKRAY et al., 1996; D'CRUZ \& WOOD, 1998; COPATTI et al., 2011).

The pirapitinga, Piaractus brachypomus, is a native fish from the Amazon and Orinoco river basins (Latin America) and can be found in acidic waters (VÁSQUEZ-TORRES, 2005). This species is a rustic, fast-growing species, prized for its meat and offering excellent conditions for culture (MELARD et al., 1993). It has considerable economic importance on a commercial scale in Colombia, Brazil, Peru, Venezuela and Central America (VÁSQUEZTORRES et al., 2002). Pirapitinga is an omnivorous species and thus its diet includes leaves, fruits, tiny

\footnotetext{
IInstituto de Oceanografia (IO), Estação Marinha de Aquacultura (EMA), Universidade Federal do Rio Grande (FURG), 96210-030, Rio Grande, RS, Brasil. E-mail: garcia log@hotmail.com. Autor para correspondência.

IIInstituto de Acuicultura de la Universidad de los Llanos (IALL), Villavicencio, Departamento de Meta, Colombia.

IIIPrograma de Pós-graduação em Zootecnia (PPGZ), Departamento de Fisiologia e Farmacologia, Universidade Federal de Santa Maria (UFSM), Santa Maria, RS, Brasil.
} 
fish, and small crustaceans. Nutritional protein requirements for pirapitinga should be approximately $32 \%$, lipid 4 to $6 \%$ and carbohydrates above $36 \%$ to achieve the best performance (VÁSQUEZ-TORRES, 2005; VÁSQUEZ-TORRES et al., 2011).

Dietary salt supplementation is very important to maintain ion homeostasis in fish exposed to low pH (D'CRUZ \& WOOD, 1998; COPATTI et al., 2011). However, to our knowledge, there are no studies regarding dietary protein levels and ionoregulation in fish exposed to acidic and alkaline $\mathrm{pH}$. In addition, no studies related to ionoregulation of pirapitinga exposed to extreme $\mathrm{pH}$ were performed. Therefore, the objective of this study was to evaluate the effects of dietary protein levels on ionoregulation and time to loose equilibrium in pirapitinga submitted to extremely acidic or alkaline $\mathrm{pH}$.

\section{MATERIAL AND METHODS}

Piaractus brachypomus juveniles were obtained from the Institute of Aquaculture at the Universidad de los Llanos, in Villavicencio, Colombia. The fish were kept in nine 200L tanks ( $\mathrm{n}=20$ per tank) in a closed system consisting of four biofilters in series, continuous flow of $2 \mathrm{~L} \mathrm{~min}^{-1} \operatorname{tank}^{-1}$. The water quality was maintained in: oxygen close to saturation $\left(7.9 \pm 0.2 \mathrm{mg} \mathrm{L}^{-1}\right)$, temperature $25.2 \pm 1.2^{\circ} \mathrm{C}, \mathrm{pH} 6.5 \pm 0.3$ and total ammonia levels $<0.02 \mathrm{mg} \mathrm{L}^{-1}$. These parameters were recorded weekly using a multiparameter probe Orion 5 Star (Thermo Electron Corporation) and total ammonia levels were measured with Ammonium test (Merck ${ }^{\circledR}$ Spectroquant 1.14752.0001).

One hundred eighty fish were separated in three treatments ( $\mathrm{n}=60$ each) and fed for 20 days with formulated experimental diets with different crude protein (CP) levels $(25.3,32.4$ or $40.0 \%)$ (Table 1). Juveniles were fed twice a day to apparent satiety and the uneaten food as well as other residues and feces were siphoned out $30 \mathrm{~min}$ after feeding.

At the end of feeding period, each treatment was subdivided in five groups of five fish each $(10.4 \pm 0.4 \mathrm{~cm}$ and $9.7 \pm 1.2 \mathrm{~g})$, that were kept in $60 \mathrm{~L}$ aquaria with $6.4 \pm 0.4 \mathrm{mg} \mathrm{L}^{-1}$ dissolved oxygen levels and temperature of $25.2 \pm 0.2^{\circ} \mathrm{C}$. Each group was exposed to a different $\mathrm{pH}(3.0,3.5,7.0,10$, or 10.5 , in duplicate). The $\mathrm{pH}$ was adjusted by adding either $\mathrm{H}_{2} \mathrm{SO}_{4}$ or $\mathrm{NaOH}(1 \mathrm{M})$. In all treatments juveniles were maintained under observation and were not fed throughout exposure to the experimental $\mathrm{pH}$.

Fish were collected from the aquaria when they showed loss of equilibrium and absence of opercular movements or at the end of the experiment
Table 1 - Diet composition used for Piaractus brachypomus juveniles in the experimental period.

\begin{tabular}{|c|c|c|c|}
\hline \multirow{2}{*}{ Ingredients } & \multicolumn{3}{|c|}{--- Crude protein (\%) ----- } \\
\hline & 25.3 & 32.4 & 40.0 \\
\hline Soybean meal & 30.0 & 30.0 & 30.0 \\
\hline Wheat bran & 23.4 & 25.0 & 21.4 \\
\hline Rice meal & 15.0 & 14.2 & 15.0 \\
\hline Whole soybean & 1.0 & 0.0 & 1.0 \\
\hline Manioc flour & 12.0 & 12.0 & 1.0 \\
\hline Whole wheat & 13.5 & 3.1 & 1.0 \\
\hline Corn gluten & 2.0 & 10.2 & 27.7 \\
\hline Meat meal & 1.0 & 1.2 & 1.0 \\
\hline Fish meal & 1.0 & 1.0 & 1.0 \\
\hline Blood meal & 1.0 & 3.1 & 0.8 \\
\hline Vitamin $\operatorname{mix}^{1}$ & 0.1 & 0.1 & 0.1 \\
\hline Mineral $\operatorname{mix}^{2}$ & 0.035 & 0.035 & 0.035 \\
\hline Proximate analysis & \multicolumn{3}{|c|}{ \% in dry matter -- } \\
\hline Dry matter & 94.5 & 93.7 & 93.4 \\
\hline Crude protein & 25.3 & 32.4 & 40.0 \\
\hline Digestible protein & 22.0 & 30.0 & 37.0 \\
\hline Gross energy ( $\mathrm{cal} \mathrm{g}^{-1}$ ) & 4455 & 4647 & 4796 \\
\hline Crude fat & 2.8 & 3.3 & 4.2 \\
\hline Ash & 5.7 & 5.8 & 5.5 \\
\hline
\end{tabular}

${ }^{1}$ Rovimix Vitamins ${ }^{\circledR}$ Lab. Roche S.A: Vit A $8.0^{*} 10^{6}$ UI, Vit D3, $1.8 * 10^{6} \mathrm{UI}$, Vit E $66.66 \mathrm{~g}$, Vit B1 $6.66 \mathrm{~g}$, Vit B2 $13.33 \mathrm{~g}$, Vit B6 $6.66 \mathrm{~g}$, Ca pantothenate $33.33 \mathrm{~g}$, Biotin $533.3 \mathrm{mg}$, folic acid $2.66 \mathrm{~g}$, ascorbic acid 400.0g, nicotinic acid 100.0g, Vit B12 20.0mg, Vit K3 6.66g, vehicle csp $1.0 \mathrm{~kg}$.

${ }^{2}$ Premix microminerals ${ }^{\circledR}$ Lab. Roche S.A.: composition for $100 \mathrm{~g}$ : magnesium 1.0, zinc 16.0 , iron 4.0 , copper 1.0 , iodine 0.5 , selenium 0.05 . cobalt 0.01 .

( $8 \mathrm{~h}$ of exposure), the blood was rapidly collected from the caudal vein with heparinized syringes and centrifuged at $2,000 \mathrm{rpm}$ for $5 \mathrm{~min}$ to separate the plasma. After sampling, all fish were euthanized by section of the spinal cord. All procedures were conducted according to rules of the Brazilian Council of Animal Experimentation Control (CONCEA). Plasma samples were stored at $-20^{\circ} \mathrm{C}$ until use. Ion plasma levels were analyzed as described by BOLNER \& BALDISSEROTTO (2007).

Data are reported here as mean \pm SEM (N). The homogeneity of variances between groups was tested with the Levene test. Comparisons of plasma ion levels between different treatments were made by a two-way ANOVA ( $\mathrm{pH} \mathrm{X} \mathrm{CP)} \mathrm{and}$ a Tukey test. All tests were performed with the software Statistica 7.0 (1997; StatSoft Inc., Tulsa, OK, USA). The linear relationships between dietary protein levels and time to lose equilibrium at the different $\mathrm{pH}$ were calculated with Sigma Plot 11.0 software (Systat Software Inc., San 
Jose, CA, USA).The minimum significance level was set at $P<0.05$.

\section{RESULTS}

The increase of the dietary protein level provided to pirapitinga increased proportionally to the time to lose equilibrium when exposed to $\mathrm{pH} 3.5$ or 10.0 , but decreased with the time to lose equilibrium after exposure to $\mathrm{pH} 3.0$ and did not affect the time to lose equilibrium after exposure to $\mathrm{pH} 10.5$ (Figure 1). The relationships between time to lose equilibrium ( $\mathrm{y}-$ in $\mathrm{min}$ ) and dietary crude protein levels $(\mathrm{x}-$ in \%) are expressed by $\mathrm{pH} 3.0 \mathrm{y}=455.88$ $7.85 \mathrm{x}\left(\mathrm{r}^{2}=0.939\right), \mathrm{pH} 3.5 \mathrm{y}=228.66+6.38\left(\mathrm{r}^{2}=0.980\right)$ and $\mathrm{pH} 10.0 \mathrm{y}=304.42+2.72\left(\mathrm{r}^{2}=0.999\right)$.

Irrespective of experimental diet, juveniles exposed to acidic water (3.0 or 3.5) showed plasma $\mathrm{Na}^{+}$levels significantly lower than those exposed to $\mathrm{pH}$ 7. However, only juveniles fed the higher dietary protein levels (32.4 and $40.0 \%$ ) and transferred to $\mathrm{pH}$ 10.0 presented significantly higher plasma $\mathrm{Na}^{+}$levels in relation to those kept at $\mathrm{pH} 7.0$ and fed the same experimental diets. Exposure to $\mathrm{pH} 10.5$ did not change plasma $\mathrm{Na}^{+}$levels. At pH 3.0 and 3.5 the juveniles fed with $32.4 \%$ CP had was significantly lower and higher plasma $\mathrm{Na}^{+}$levels, respectively, compared to those fed with 25.3 and $40.0 \% \mathrm{CP}$ at these same $\mathrm{pH}$. Juveniles fed $32.4 \% \mathrm{CP}$ and transferred to $\mathrm{pH} 10.0$ showed plasma $\mathrm{Na}^{+}$levels significantly higher than those fed with $25.3 \% \mathrm{CP}$ (Figure 2A).
Juveniles fed with all experimental diets and transferred to both acidic and alkaline $\mathrm{pH}$ showed significantly lower plasma $\mathrm{Cl}^{-}$levels than those maintained at $\mathrm{pH} 7.0$ (Figure 2B). Juveniles exposed to acidic (3.0 and 3.5) and alkaline (10.0) $\mathrm{pH}$ presented significantly higher plasma $\mathrm{K}^{+}$levels than those maintained at $\mathrm{pH} 7.0$ and 10.5 irrespective of experimental diets. The plasma $\mathrm{K}^{+}$levels of the juveniles exposed to $\mathrm{pH} 3.0$ and fed with the diet containing $32.4 \%$ CP were significantly lower than those fed with with $25.3 \% \mathrm{CP}$ at the same $\mathrm{pH}$ (Figure 2C).

\section{DISCUSSION}

The increase of dietary protein levels increased the time for pirapitinga to lose equilibrium at $\mathrm{pH} 3.5$ or 10.0. This result indicates that a higher dietary protein level could be tested to improve survival and/or growth of this species at less acidic or alkaline waters. However, as the diet with higher protein level also presented around 7\% higher gross energy, it is not possible to exclude that dietary energy may also contribute to this variation. In agreement with the present study, rainbow trout fed with $39 \%$ digestible protein (energy content $16.3 \mathrm{Mj} \mathrm{kg}^{-1}$ ) presented higher growth and food conversion efficiency than those fed with $23 \%$ digestible protein (energy content $9.8 \mathrm{Mj} \mathrm{kg}^{-1}$ ) when maintained at pH 5.2 (D'CRUZ \& WOOD, 1998).

Pirapitinga juveniles submitted to acute acidic exposure ( $\mathrm{pH} 3.0$ or 3.5) presented $\mathrm{Na}^{+}$and $\mathrm{Cl}^{-}$loss in comparison with fish exposed to neutral

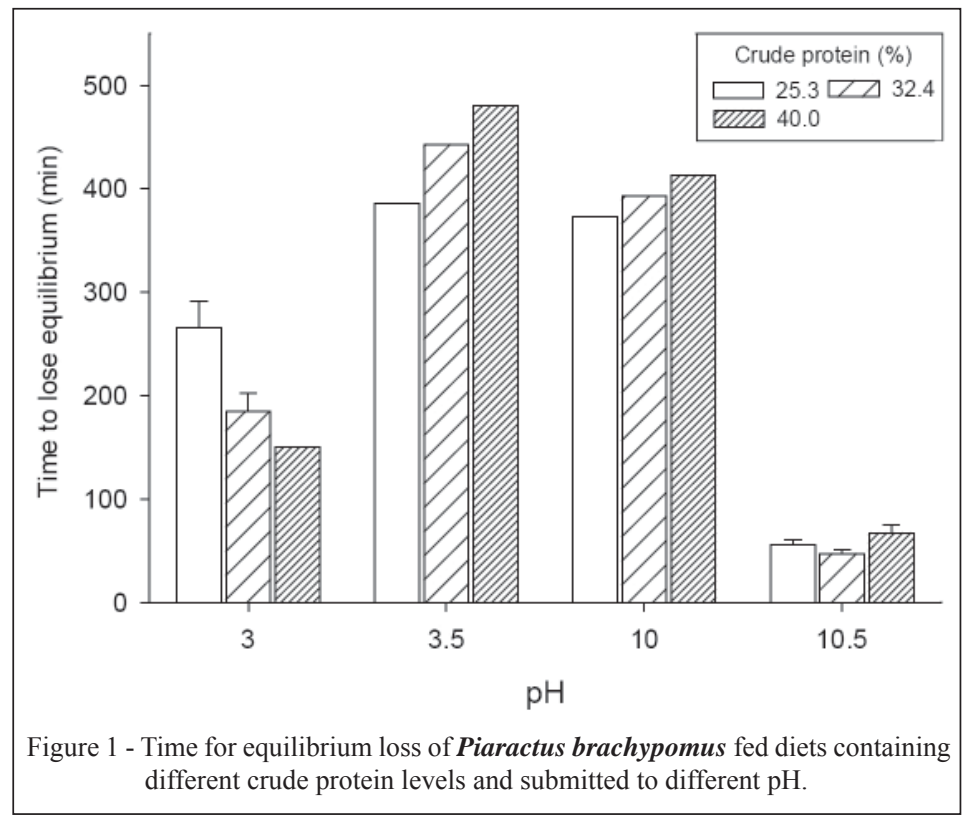

Ciência Rural, v.44, n.2, fev, 2014. 


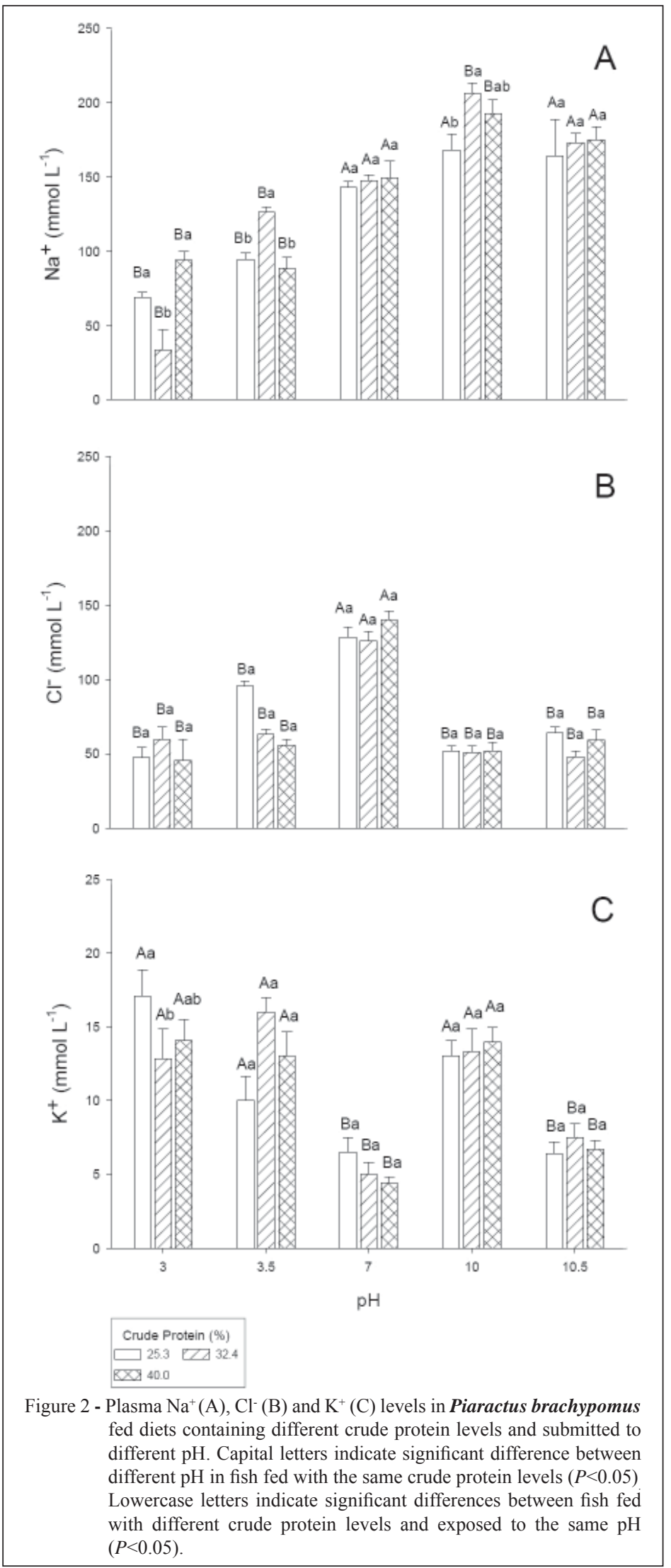

Ciência Rural, v.44, n.2, fev, 2014. 
pH. The same was described for other species exposed to acidic $\mathrm{pH}$ : common carp Cyprinus carpio (pH 4.0) (CHEZHIAN et al., 2011), pupfish Cyprinodon variegatus variegatus (BRIX et al., 2013) zebrafish Danio rerio (KWONG \& PERRY, 2013) and silver catfish (pH 4.0 and 5.5) (ZAIONS \& BALDISSEROTTO, 2000; COPATTI et al., 2011). In acidic waters the uptake of $\mathrm{Na}^{+}$and $\mathrm{Cl}^{-}$is probably inhibited due to a competition of $\mathrm{H}^{+}$with $\mathrm{Na}^{+}$transport sites (PARRA \& BALDISSEROTTO, 2007). In addition, high $\mathrm{H}^{+}$disrupt the tight junctions of gill epithelia causing greater ionic loss by paracelullar route (KUMAI et al., 2011; KWONG \& PERRY, 2013), and the net $\mathrm{H}^{+}$excretion by the $\mathrm{H}^{+}$ATPase observed in neutral waters is reduced (BRIX et al., 2013). Higher plasma $\mathrm{K}+$ levels after exposure to acidic $\mathrm{pH}$ ( $\mathrm{pH}$ 5.0) was also observed in common carp (MATHAN et al., 2010). These authors supposed that this elevation is due to intracellular $\mathrm{K}^{+}$release from muscles as $\mathrm{H}^{+}$enters.

In alkaline waters, ion loss probably occur due to an inhibition of branchial $\mathrm{Na}^{+} / \mathrm{H}^{+}$and $\mathrm{Cl}^{-} /$ $\mathrm{HCO}_{3}$ exchangers (PARRA \& BALDISSEROTTO, 2007), which would explain the lower plasma $\mathrm{Cl}^{-}$ levels in pirapitinga at $\mathrm{pH} 10.0$ and 10.5. Ions loss after exposure to alkaline waters also occurred in silver catfish at $\mathrm{pH}$ 9.4-10.0 (ZAIONS \& BALDISSEROTTO, 2000), O. mykiss at pH 9.0-10.5 (YESAKI \& IWAMA, 1992; McGEER \& EDDY, 1998) and Oncorhynchus clarki henshawi at 10.010.5 (WILKIE et al., 1994). However, exposure of pirapitinga to alkaline $\mathrm{pH}$ did not change or increased (at $\mathrm{pH} 10.0$ in fish fed the higher dietary protein levels) plasma $\mathrm{Na}^{+}$levels. Apparently alkaline water has a different effect on $\mathrm{Na}^{+}$and $\mathrm{Cl}^{-}$transporters. Similar effects on $\mathrm{Na}^{+}$and $\mathrm{Cl}^{-}$plasma levels were observed in silver catfish exposed to $\mathrm{pH} 9.0$ for $24 \mathrm{~h}$ (BOLNER \& BALDISSEROTTO, 2007).

The increase of dietary protein (and energy) levels did not improve the ionoregulatory response of pirapitinga against acidic or alkaline $\mathrm{pH}$ exposure. Higher dietary energy and protein level also did not improve the ionoregulatory response in rainbow trout exposed to pH 5.2 (D'CRUZ \& WOOD, 1998).

In conclusion, the increase of dietary protein levels (with a possible contribution of dietary energy) increased the time for pirapitinga to lose equilibrium at $\mathrm{pH} 3.5$ or 10.0 , but was not effective for compensating ion loss at very acidic $\left(\mathrm{Na}^{+}\right.$and $\left.\mathrm{Cl}^{-}\right)$ and alkaline $\left(\mathrm{Cl}^{-}\right) \mathrm{pH}$.

\section{ACKNOWLEDGMENTS}

B. Baldisserotto received a Conselho Nacional de Desenvolvimento Científico e Tecnológico (CNPq) research fellowship.

\section{REFERENCES}

BOLNER, K.C.S.; BALDISSEROTTO, B. Water $\mathrm{pH}$ and urinary excretion in silver catfish Rhamdia quelen. Journal of Fish Biology, v.70, p.50-64, 2007. Available from: $<$ http://onlinelibrary. wiley.com/doi/10.1111/j.1095-8649.2006.01253.x/pdf > Accessed: out. 10, 2012. doi:10.1111/j.1095-8649.2006.01253.x.

BRIX, K.V. et al. Measuring titratable alkalinity by single versus double endpoint titration: an evaluation in two cyprinodont species and implications for characterizing net $\mathrm{H}^{+}$flux in aquatic organisms. Comparative Biochemistry and Physiology Part A, v.164, p.221-228, 2013. Available from: <http://www.sciencedirect.com/ science/article/pii/S1095643312004734>. Accessed: jul. 22, 2013. doi: 10.1016/j.cbpa.2012.09.010

CHEZHIAN, A. et al. Influence of different calcium levels and low $\mathrm{pH}$ of water on the plasma electrolyte regulation of a fresh water teleost fish Cyprinus carpio var. communies, (Linnaeus, 1958). Current Research Journal of Biological Sciences, v.3, n.2, p.147-154, 2011. Available from: <http://maxwellsci.com/ print/crjbs/v3-147-154.pdf>. Accessed: may. 10, 2013.

COPATTI, C.E. et al. Dietary salt and water $\mathrm{pH}$ effects on growth and $\mathrm{Na}^{+}$fluxes of silver catfish juveniles. Acta Scientiarum Animal Science, v.33, n.3, p.261-266, 2011. Available from: $<$ http://periodicos.uem.br/ojs/index.php/ActaSciAnimSci/article/ view/11192/11192>. Accessed: out. 10, 2012. doi: 10.4025/ actascianimsci.v33i3. 11192.

D'CRUZ, L.M.; WOOD, C.M. The influence of dietary salt and energy on the response to low $\mathrm{pH}$ in juvenile rainbow trout. Physiological Zoology, v.71, n.6, p. 642-657, 1998. Available from: <http://www.jstor.org/stable/10.1086/515987>. Accessed: out. 10,2012

DOCKRAY, J.J. et al. Effect of elevated summer temperatures and reduced $\mathrm{pH}$ on metabolism and growth of juvenile rainbow trout (Oncorhynchus mykiss) on unlimited ration. Canadian Journal of Fisheries and Aquatic Science, v.25, p.2752-2763, 1996. Available from: <http://www.nrcresearchpress.com/doi/ pdf/10.1139/f96-232>. Accessed: out. 10, 2012. doi: 10.1139/ f96-232.

KUMAI, Y. et al. Strategies for maintaining $\mathrm{Na}^{+}$balance in zebrafish (Danio rerio) during prolonged exposure to acidic water. Comparative Biochemistry and Physiology Part A, v.160, n.1, p.52-62, 2011. Available from: <http://www.sciencedirect.com/ science/article/pii/S1095643311001310>. Accessed: jul. 22, 2013. doi: 10.1016/j.cbpa.2011.05.001.

KWONG, R.W.; PERRY, S.F. Cortisol regulates epithelial permeability and sodium losses in zebrafish exposed to acidic water. Journal of Endocrinology, v.217, n.3, p.253-64, 2013. Available from: $\quad<$ http://joe.endocrinology-journals.org/content/217/3/253. short>. Accessed: jul. 22, 2013. doi: 10.1530/JOE-12-0574.

MATHAN, R. et al. Alterations in plasma electrolyte levels of a freshwater fish Cyprinus carpio exposed to acidic $\mathrm{pH}$. Toxicological and Environmental Chemistry, v.92, n.1, p.149-157, 2010. Available from: <http://www.ingentaconnect. com/content/tandf/gtec/2010/00000092/00000001/art00017>. Accessed: may 22, 2013. doi: 10.1080/02772240902810419.

McGEER, J.C.; EDDY, F.B. Ionic regulation and nitrogenous excretion in rainbow trout exposed to buffered and unbuffered 
freshwater of $\mathrm{pH}$ 10.5. Physiological Zoology, v.71, n.2, p.179-190, 1998. Available from: <http://www.jstor.org/ stable/10.1086/515895>. Accessed: out. 10, 2012.

MELARD, C.H. et al. Comparative growth rate and production of Colossoma macropomum and Piaractus brachypomus (Colossoma bidens) in tanks and cages using intensive rearing conditions. In: BARNABE, G.; KESTEMONT, P. (Eds.). Production, environment and quality. Ghent: European Aquaculture Society, 1993. Cap.39, p.433-442. (Special Publication 18)

PARRA, J.E.G.; BALDISSEROTTO, B. Effect of water pH and hardness on survival and growth of freshwater teleosts. In: BALDISSEROTTO, B. et al. (Ed.). Fish osmoregulation. New Hampshire: Science Publishers, 2007. Cap.5, p.135-150.

VÁSQUEZ-TORRES, W. et al. Estudos para composição de uma dieta referência semipurificada para avaliação das exigências nutricionais em juvenis de pirapitinga, Piaractus brachypomus (Cuvier 1818). Revista Brasileira de Zootecnia, v.31, p.283292, 2002. Available from: <http://www.scielo.br/pdf/rbz/ v31n1s0/10307.pdf>. Accessed: out. 10, 2012. doi: 10.1590/ S1516-35982002000200001.

VÁSQUEZ-TORRES, W. A Pirapitinga, reprodução e cultivo. In: BALDISSEROTTO, B.; GOMES, L.C. (Ed.). Espécies nativas para piscicultura no Brasil. Santa Maria: UFSM, 2005. Cap.9, p.203-223.

VÁSQUEZ-TORRES, W. et al. Optimum dietary crude protein requirement for juvenile cachama Piaractus brachypomus. Ciência
Rural, v.41, n.12, p.2183-2189, 2011. Available from: <http:// www.scielo.br/pdf/cr/v41n12/a21011cr5219.pdf $>$. Accessed: out. 10, 2012. doi: 10.1590/S0103-84782011001200023.

WILKIE, M.P. et al. Physiological adaptations of rainbow trout to chronically elevated water $\mathrm{pH}(\mathrm{pH}$ 9.5). Journal of Experimental Zoology, v.274, p.1-14, 1996. Available from: $<$ http://onlinelibrary. wiley.com/doi/10.1002/(SICI)1097-010X(19960101)274:1\% 3C1::AID-JEZ1\%3E3.0.CO;2-T/pdf>. Accessed: out. 10, 2012. doi: 10.1002/(SICI)1097-010X(19960101)274

WILKIE, M.P. et al. The physiological adaptations of the Lahontan cutthroat trout (Oncorhynchus clarki henshawi) following transfer from well water to the highly alkaline waters of Pyramid Lake, Nevada (pH 9.4). Physiological Zoology, v.67, p.355-380, 1994. Available from: <http://www.jstor.org/stable/30163853>. Accessed: out. 10, 2012.

YESAKI, T.Y.; IWAMA, G.K. Survival, acid-base regulation, and ammonia excretion in rainbow trout in highly alkaline hard water. Physiological Zoology, v.65, n.4, p.763-787, 1992. Available from: <http://www.jstor.org/stable/30158538>. Accessed: out. 10, 2012 .

ZAIONS, M.I.; BALDISSEROTTO, B. $\mathrm{Na}^{+}$and $\mathrm{K}^{+}$body levels and survival of juveniles of Rhamdia quelen (Siluriformes, Pimelodidae) exposed to acute changes of water $\mathrm{pH}$. Ciência Rural, v.30, n.6, p.1041-1045, 2000. Available from: <http:// www.scielo.br/pdf/cr/v30n6/a20v30n6.pdf >. Accessed: out. 10, 2012. doi: $10.1590 / \mathrm{S} 0103-84782000000600020$. 